\title{
Recycled C\&D waste- An energy efficient and sustainable construction material
}

\author{
Madan Chandra Maurya $^{1 *}$, Dinesh Kumar Malviya ${ }^{2}$ \\ ${ }^{I}$ Department of Civil Engineering, Madan Mohan Malaviya University of Technology, Gorakhpur, India \\ ${ }^{2}$ GE Division, CSIR-Central Building Research Institute, Roorkee, India \\ *Corresponding Author: e-mail: mcmce@mmmut.ac.in, Tel +91-8765783659 \\ ORCID iDs: https://orcid.org/0000-0002-1211-2048(Maurya), https://orcid.org/0000-0001-8396-7636 (Malviya)
}

\begin{abstract}
Construction and demolition (C\&D) wastes are generated with construction or demolition activities and consists of non biodegradable materials such as cement concrete, bricks, plaster, steel, rubble, woods, plastics etc. Large use of natural recourses for the production of construction materials such as concrete is a prime concern for sustainability. In order to minimize the environmental impacts in terms of energy consumption, pollution, waste disposal and global warming construction industries has started to look for new alternative sources which are capable of substituting the use of natural materials, also some attempts were taken to utilize the waste generated from the demolition of structures and construction activity. The main benefits from the recycling of $\mathrm{C} \& \mathrm{D}$ waste are conservation of natural resources, reduction in energy consumption, solution for waste disposal crisis, environment preservation. Its use reduces reliance on primary aggregates and lowers the environmental impact of construction.
\end{abstract}

Keywords: Construction and demolition, Environment, Energy, Sustainability.

DOI: http://dx.doi.org/10.4314/ijest.v13i1.18S

Cite this article as:

Maurya M.C., Malviya D.K. 2021. Recycled C \& D waste- an energy efficient and sustainable construction material. International Journal of Engineering, Science and Technology, Vol. 13, No. 1, pp. 119-124. doi: 10.4314/ijest.v13i1.18S

Received: December 1, 2019; Accepted: February 5, 2021; Final acceptance in revised form: March 31, 2021

This paper was earlier presented at the International Conference on Energy, Environment \& Material Sciences (ICE2M), 1-3 December 2019 and substantially improved for this Special Issue. Guest Editor: Dr. Sri Niwas Singh, Professor (HAG), Department of Electrical Engineering, Indian Institute of Technology Kanpur, 208016 (U.P.) India, former Vice-Chancellor, Madan Mohan Malviya University of Technology Gorakhpur (April 2017 to July 2020).

\section{Introduction}

Due to rapid urbanization, the extraction and production of raw materials such as sand (for concrete and mortar), soil (for clay bricks), stone (for aggregates) and limestone (for cement) will have significant ecological impact. India's construction industry is expected to grow at a rate of 7-8\% over the next decade (NitiAyog, 2018). The generation of enormous quantity of C\&D waste is especially expected in older cities, due to demolition of existing old buildings. Management of such huge waste is a challenge for every country; however, some countries such as Hong Kong, Taiwan, United States of America, Belgium, Denmark, Germany, Netherlands, Germany, France, Japan have started to reuse their C\&D waste up to some extent. Lack of demolition experience and knowledge of their use makes them waste material. In Indian scenario, out of these wastes some items such as metal rods, pipe and fixtures, wooden frames were sold leaving behind the rubble composed of bulky materials such as concrete, stones, bricks, mortars etc. Sometimes these rubbles were utilized for back-filling in construction projects but most portions is disposed either in 
designated landfills or often in unauthorized places such as road sides, river beds, low lying areas that causes environmental and safety problems to inhabitants.

Use of recycled $C \& D$ wastes has reduced the environmental concerns by the aggregate consumption of construction industry. Many successful applications (Akbulut and Gurer, 2007; Arulrajah et al. 2013; Asprone et al. 2015; Bennert et al., 2000; Disfani et al., 2012; Rahmann et al., 2014) were reported around the world. Materials recovered from the C\&D sector accounts significant percentage and in few cases (Sustainability Victoria, 2013) it reached to almost half of the recovered material out of which half alone was concrete, which is approximately $25 \%$ of total reprocessing. For the wide application of C\&D waste a sound framework is needed to be established. Several researchers (Elhakam et al. 2012; Kou et al. 2008; Kwan et al., 2011; Zhuang et al., 2012) have attempted more detailed studies on C\&D wastes.

\section{Typical Composition of C \& D Waste}

Population growth, industrial development, construction growth creates huge amount of C\&D waste. Among these, construction industry is a major consumer of natural resources and the global production of aggregates almost doubled in 7 seven years from 21 billion to 40 billion tons in 2014. Production of 40 billion tons of global aggregates shows the ongoing vast development projects all around the world.
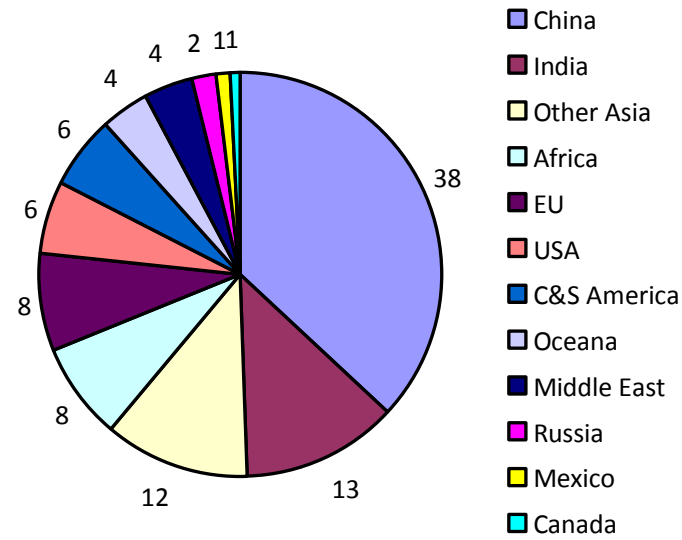

Fig. 1. Global aggregate production (Slattery, 2016).

Due to scarcity of natural material and land both, an alternative to use the enormous available C\&D waste is gaining importance. However, research and development is highly required for its sustainable utilization as a construction material. Some developing nations such as Australia, Western Europe, America has shown considerable progress in adopting C\&D waste management system, however major C\&D waste producing countries such as China, India, Indonesia, Malaysia, Thailand, Gulf States, Brazil, Mexico are way behind to above developing nations in adopting the $C \& D$ waste management system. India also produces a significant amount of waste, which is not being utilized very well. Significant amount of waste could be used with the development of proper management system. Lack of technical expertise and awareness among the people leads this useful material to go in vain. Proper knowledge and management system could solve of scarcity of construction materials, which istotally dependent upon the natural materials in current scenario.
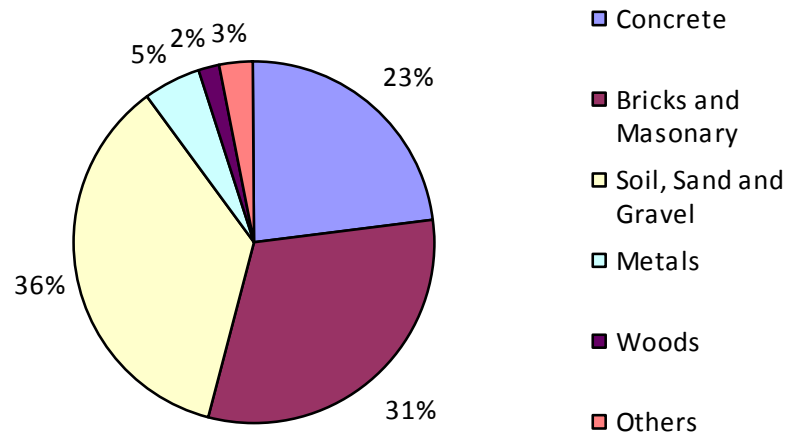

$\square$ Others

Fig. 2. C\&D Waste in India (TIFAC, 2001) 
The data in Table 1 shows the C\&D waste generation in some selected cities of India, however the amount will be significantly high if taken collectively for the whole country. Our country has huge potential to utilize this waste. Regulations and legislation by the government authority in our country could be helpful in structuring and constituting a market for building material and products derived from the C\&D waste.

Table 1. C \& D waste generation in selected Indian cities (GIZ and DIA, 2015).

\begin{tabular}{|c|c|c|c|}
\hline City & $\begin{array}{l}\text { Population (Census } \\
\text { 2011, in millions) }\end{array}$ & $\begin{array}{c}\text { Daily C\&D waste } \\
\text { generation (tonnes/day) }\end{array}$ & $\begin{array}{c}\text { Annual C\&D waste generation } \\
\text { (million tonnes/annum) }\end{array}$ \\
\hline Mumbai & 12.44 & 2500 & 0.75 \\
\hline Delhi & 16.78 & 4600 & 1.38 \\
\hline Bengaluru & 8.44 & 875 & 0.26 \\
\hline Chennai & 6.50 & 2500 & 0.75 \\
\hline Kolkata & 4.49 & 1600 & 0.48 \\
\hline Jaipur & 3.47 & 200 & 0.06 \\
\hline Patna & 2.51 & 250 & 0.08 \\
\hline Ahmedabad & 6.06 & 700 & 0.21 \\
\hline Bhopal & 1.91 & 50 & 0.02 \\
\hline Coimbatore & 2.61 & 92 & 0.03 \\
\hline
\end{tabular}

\section{Recycling C \& D Waste}

Recycling C\&D waste has huge potential to create a separate sustainable market for the construction industry. The life of a building could be categorized generally into three phases such as construction, renovation and demolition. Among all the phases demolition phase produces the maximum waste aggregates, which could be utilized for variety of application, if managed properly with utmost care. Recycled aggregates could be obtained from these wastes after allowing them to the crushing plants. Flow chart in Fig. 3 shows the steps involved in crushing plant to obtain reusable aggregates from the C\&D wastes. Waste material is allowed for primary crushing initially, followed by primary, magnetic and secondary screening. After these screening, the residual were removed and secondary crushing is allowed.

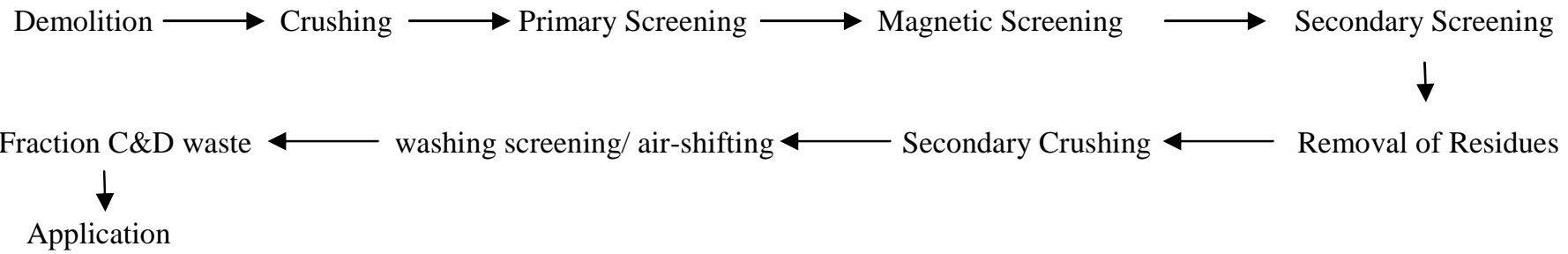

Fig. 3. Typical crushing plant process for recycled aggregate production ( $\mathrm{Ng}$ and Engelsen, 2018).

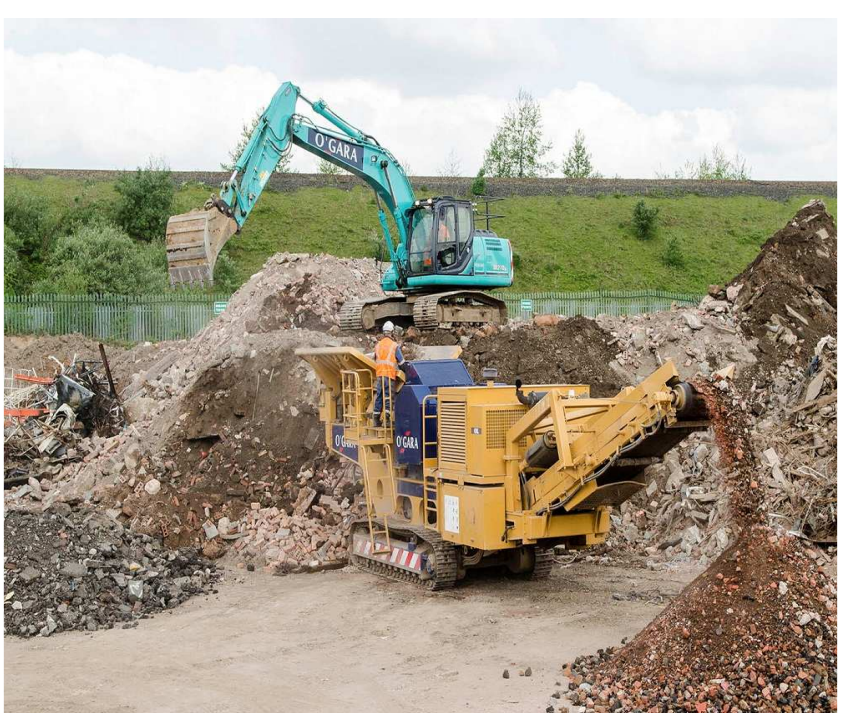

Fig. 4. Typical C\&D waste recycling site (http://ogara.co.uk/recycled-soils-aggregates.php). 
The crushed material is allowed for washing screening, air shifting and the obtained fraction of C\&D waste at this stage is utilized for various applications. Most of the processing plants were operating on the similar pattern with smallmodifications as per the requirement of the waste materials at the site. Initially the sorting of the waste materials were performed manually, the mechanical operation were performed only with recyclable materials. The non-recyclable materials obtained in C\&D waste were not allowed in this process and disposed.

\section{Benefits of Recycling C \& D Waste}

Recycling C\&D waste could solve some of our potential problems which the world is facing nowadays. It is well known that production of construction materials effects adversely to the environment by generation toxic gases and harmful chemicals as by product. Also, their manufacturing utilizes good amount of money which again affects the economy. Recycling not only minimizes the production of the materials but also protect environment by reducing the $\mathrm{CO}_{2}$ footprints. Less production leads to less harnessing of natural resources which helps in their conservation, also the proper utilization could be helpful in improving the health conditions of the locality. Since most of these waste materials are hazardous, they disposal in open space should be avoided. Reducing carbon footprints would be helpful in maintaining balance in the environment.

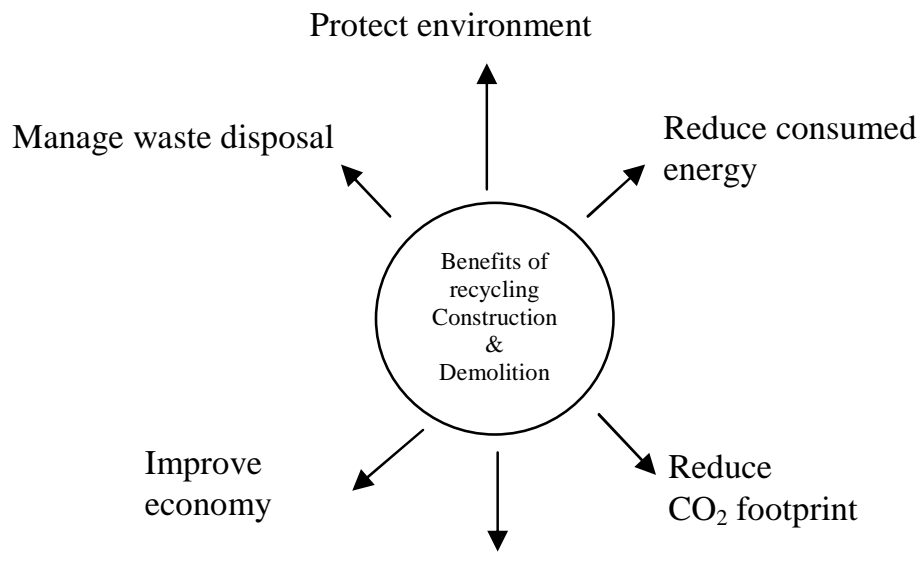

Conserve natural resources

Fig. 5. Benefits from recycling C\&D waste (Ng ad Engelsen, 2018).

Many developed countries in the Europe have good ratio in the production of total aggregates and production of recycled aggregates. The economic conditions of these nations are much better when compared with their counterparts. The utilization of recycled products should be implemented in the Asian countries as well. A huge C\&D wastes are generated in this region, but proper management system is not adopted yet. A proper utilization could solve serious issues in this region.

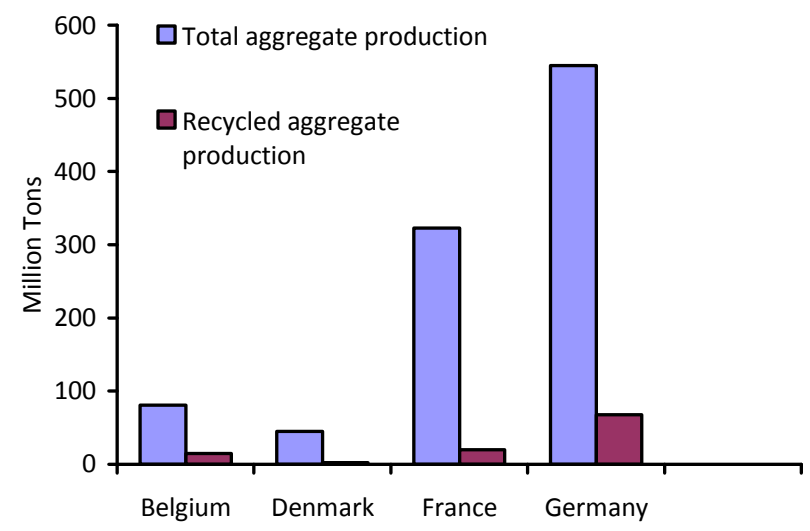

Fig. 6. Comparison of Total aggregates production and recycled aggregate production (UEPG, 2016). 


\section{Issues for Recycled Aggregate Usage}

Various factors such as limiting standards and guidelines, low supply and demand, lack of recycling facility, perception of the customer etc. acts as a barrier for recycled aggregates to be used as an alternative to conventional construction materials.

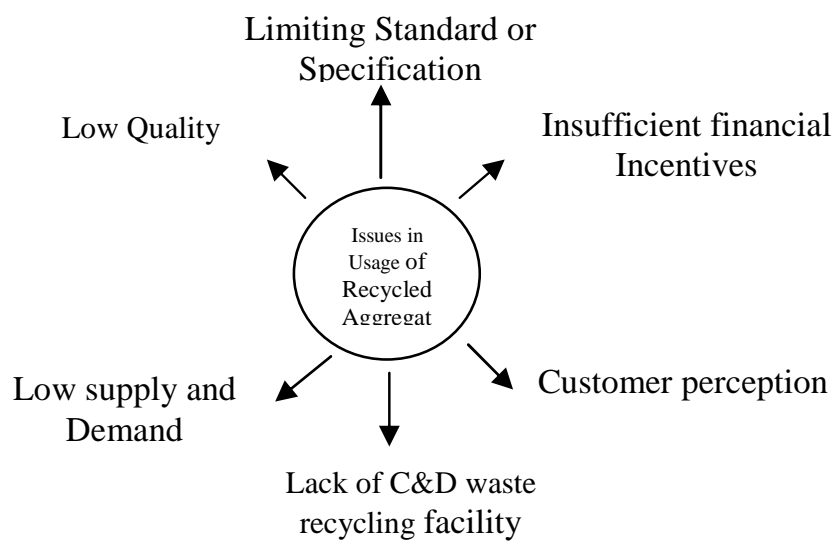

Fig. 7. Obstructions preventing the wider application of recycled aggregates in construction industry (Silva et al., 2017).

However, if proper care is taken by the policy makers in resolving these issues, the C\&D wastes could be accepted for variety of applications. The quality of these recycled aggregates is still needed to be addressed.

\section{Conclusion}

Proper utilization of C\&D wastes has potential to solve many serious issues which were faced all around the world. Rapid infrastructural demands have raised serious problem related to supply of the construction materials. Having limited natural resources, it is impossible to fulfill the demand of future constructions. Recycled aggregated could be a good alternative in such cases and solve serious problems of environmental impact due to production of new materials.More studies leading to specification and guidelines will behelpful for the common people to adopt these materials as sustainable construction materials.

\section{Acknowledgement}

We are sincerely grateful to the referees for their valuable comments which have helped in improving the overall clarity and readability of this article.

\section{References}

Akbulut, H., Gurer, C. 2007. Use of aggregates produced from marble quarry waste in asphalt pavements. Building and Environmnet, Vol. 42, pp. 1921-1930.https://doi.org/10.1016/j.buildenv.2006.03.012

Arulrajah, A., Piratheepan, J., Disfani, M. M., Bo, M. W. 2013. Geotechnical and Geoenvironmental Properties of Recycled Construction and Demolition Materials in Pavement Subbase Applications.Journal of Materials in Civil Engineering, Vol. 25 (8), pp. 1077-1088.https://doi.org/10.1061/(ASCE)MT.1943-5533.0000652

Asprone, D., Bilotta, E., Capasso, I., Caputo, D., Flora, A., Liguori, B., Lirer, S. 2015. Re use of construction and demolition waste for geotechnical applications.Geotechnical Engineering for Infrastructure and Development, pp. 25892594.https://www.icevirtuallibrary.com/doi/abs/10.1680/ecsmge.60678.vol5.399

Bennert, T., Papp, W. J., Maher, A., Gucunski, N. 2000. Utilization of Construction and Demolition Debris Under Traffic-Type Loading in Base and Subbase Applications.Transport Research Record 1714, Paper no 1350, pp 33-39. https://doi.org/10.3141/1714-05

Disfani, M., M., Arulrajah, A., Bo, M., W., Sivakugan, N. 2012. Environmental risks of using recycled crushed glass in road applications. Journal of Cleaner Production, Vol. 20, pp. 170-179.https://doi.org/10.1016/j.jclepro.2011.07.020

Elhakam, A. A., Mohamed, A., E., Awad, E. 2012. Influence of self-healing, mixing method and adding silica fume on mechanical properties of recycled aggregates concrete.Construction and Building Materials, Vol. 35, pp. 421-427.

https://doi.org/10.1016/j.conbuildmat.2012.04.013 
GIZ and DA. 2008. Resource Efficiency in the Indian Construction Sector: Market Evaluation of the Use of Secondary Raw Materials from Construction and Demolition Waste. New Delhi.

Kou, S., C., Poon, C., S. 2008. Mechanical properties of 5-year-old concrete prepared with recycled aggregates obtained from three different sources.Magazine of Concrete Research, Vol. 60 (1), pp. 57-64.https://doi.org/10.1680/macr.2007.00052

Kwan, W., H., Ramli, M., Kam, K., J., Sulieman, A., Z. 2011. Influence of the amount of recycled coarse aggregate in concrete design and durability properties.Construction and Building Materials, Vol. 26 (1), pp. 565-573. https://doi.org/10.1016/j.conbuildmat.2011.06.059

Ng, S, Engelsen, C., J. 2018. Construction and Demolition wastes. Water and Supplementary Cementious materials in Concrete, pp. 229-255. https://doi.org/10.1016/B978-0-08-102156-9.00008-0

NITI Ayog, "Strategy for Promoting Processing of Construction and Demolition (C\&D) Waste and Utilisation of Recycled Products," 2018.

Rahman, M., Imteaz, M., Arulrajah, A., Disfani, M. 2014. Suitability of recycled construction and demolition aggregates as alternative pipe backfilling materials.Journal of Cleaner Production, Vol. 66, pp. 7584.https://doi.org/10.1016/j.jclepro.2013.11.005

Silva, R., V., Brito, D., De., Dhir, R., K. 2017. Availibility and processing of recycled aggregates within the construction and demolition supply chain- A review. Journal of Cleaner Production, Vol. 143, pp. 598-614. https://doi.org/10.1016/j.jclepro.2016.12.070

Slattery, K. 2016. Global developments in the aggregate industry- Global aggregates information Network.

Sustainability Victoria. 2013. Victorian recycling industries annual report 2011-12. Melbourne, VIC, Australia.

TIFAC. 2001. Utilization of waste from construction industry. New Delhi: Technology Information, Forecasting and Assessment Council.

UEPG. 2016. European Aggregates Association- Annual review (2015-2016)..

Zhuang, X., J., Gui, L., I., W., Sun, P., C. 2012. Recent studies on mechanical properties of recycled aggregate concrete in China-A review. Science China Technological Sciences, Vol. 55 (6), pp. 1463-1480.https://doi.org/10.1007/s11431-012$4786-9$

\section{Biographical notes}

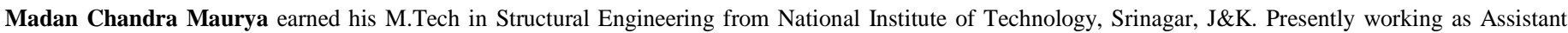

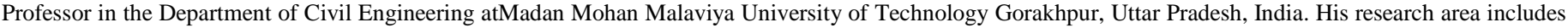
Finite Element Analysis, Composite Material, High Performance Concrete, Design of RCC Bridges \& Buildings \& Advanced FGM based Composite Material.

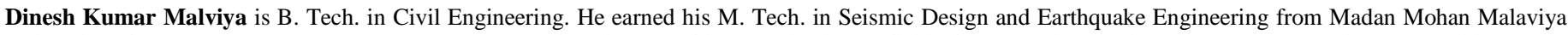

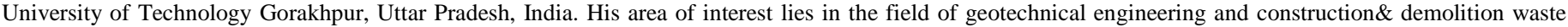
materials. He has presented papers in national conferences. 